Georgia State University

ScholarWorks @ Georgia State University

$9-16-2019$

\title{
Taking Control of Regulations: How International Advocacy NGOs Shape the Regulatory Environments of their Target Countries
}

Andrew Heiss

Georgia State University, aheiss@gsu.edu

Follow this and additional works at: https://scholarworks.gsu.edu/pmap_facpubs

Part of the Public Affairs, Public Policy and Public Administration Commons

\section{Recommended Citation}

Heiss, Andrew, "Taking Control of Regulations: How International Advocacy NGOs Shape the Regulatory Environments of their Target Countries" (2019). PMAP Publications. 28.

https://scholarworks.gsu.edu/pmap_facpubs/28

This Article is brought to you for free and open access by the Department of Public Management and Policy at ScholarWorks@ Georgia State University. It has been accepted for inclusion in PMAP Publications by an authorized administrator of ScholarWorks @ Georgia State University. For more information, please contact scholarworks@gsu.edu. 
June 20, 2019. Published in Interest Groups and Advocacy, 8, no. 3 (September 2019): 356-75, doi: 10.1057/s41309-019-00061-0.

\title{
Taking Control of Regulations: How International Advocacy NGOs Shape the Regulatory Environments of their Target Countries
}

\author{
Andrew Heiss \\ Georgia State University \\ aheiss@gsu.edu
}

\begin{abstract}
A wave of legislative and regulatory crackdown on international nongovernmental organizations (INGOs) has constricted the legal environment for foreign advocacy groups interested in influencing domestic and global policy. Although the legal space for advocacy is shrinking, many INGOs have continued their work and found creative ways to adapt to these restrictions, sometimes even reshaping the regulatory environments of their target countries in their favor. In this article, I explore what enables INGOs to cope with and reshape their regulatory environments. I bridge international relations and interest group literatures to examine the interaction between INGO resource configurations and institutional arrangements. I argue that the interaction between resources and institutions provide organizations with 'programmatic flexibility' that enables them to adjust their strategies without changing their core mission. I illustrate this argument with case studies of Article 19 and AMERA International and demonstrate how organizations with high programmatic flexibility can navigate regulations and shape policy in their target country, while those without this flexibility are shut out of policy discussions and often the target country itself. I conclude by exploring how the interaction between internal characteristics and institutional environments shape and constrain the effects of interest groups in global governance.
\end{abstract}

Legal crackdowns against international nongovernmental organizations (INGOs) have increased substantially since 20oo. Dozens of authoritarian countries have passed harsh new anti-NGO regulations, including Russia, Egypt, China, Bahrain,

*I thank Elizabeth Bloodgood and Lisa Dellmuth for their invaluable editorial and theoretical suggestions, Nina Hall, Laura Henry, and Lisa Sundstrom for their insightful comments, and the participants of the 'Interest Groups, International Organizations, and Global Problem-Solving Capacity' workshop held at Stockholm University in June 2018 for their support and assistance. 
Kazakhstan, and Azerbaijan. In 2017, CIVICUS reported that only $3 \%$ of the world's population lives in countries that impose minimal restrictions on associational activity, while most face obstructed or repressed civic space (CIVICUS 2017). However, while the legal space for global advocacy organizations is closing, many INGOs continue to work in their target countries by finding creative ways to adapt to more restrictive regulations. In some cases, international interest groups have adapted so well that they have been able to shape the regulatory environment of their target countries in their favor. What enables international advocacy NGOs to cope with repressive regulations, achieve advocacy goals, and influence their regulatory environments?

We can explore possible answers to this question by combining research on INGOs and interest groups. International advocacy NGOs fit well into the category of 'interest group' - these organizations attempt to affect government policy and influence the public good, both in domestic politics and in global governance institutions. Moreover, we can use the concept of opportunity structures to theorize the conditions under which INGOs can have advocacy effects under repressive regulations. In this paper, I examine the interaction between two of the opportunity structures identified by Dellmuth and Bloodgood (this special issue): resource configurations and institutional arrangements. In research on interest groups, institutional arrangements define the strategies available to advocacy organizations. Research on INGOs and nonprofit organizations, on the other hand, has tended to look at how the internal characteristics of INGOs or how the links and relationships between INGOs enable these organizations to be effective in global governance (Dellmuth and Tallberg 2017; Wong 2012). The effects of institutional environments and the interaction between INGO resources and institutional arrangements are relatively unexplored within international relations and interest groups literatures (Bloodgood, Tremblay-Boire, and Prakash 2014; Heiss and Johnson 2016; Tallberg et al. 2018) .

In this paper, I bridge research in international relations, nonprofit management, and interest groups to examine how the interaction between resource configurations and institutional constraints provides INGOs with what I term 'programmatic flexibility', or the ability to navigate and adapt to the institutional constraints they face and achieve their advocacy goals without losing mission focus. I examine how resource configurations and institutional factors influence INGO strategy and propose my primary argument: programmatic flexibility permits INGOs to respond to repressive regulations designed to limit their ability to engage in advocacy, and organizations that adapt to these regulations are well-positioned to then shape those regulations in their favor. I illustrate this argument with case studies of Article 19 and AMERA International, demonstrating how organizations with high programmatic flexibility are able to navigate strict regulations and potentially shape do- 
mestic policy in their target country, while those lacking this flexibility are shut out of policy discussions and, eventually, the target country itself. I conclude by addressing the central theoretical argument of this issue, exploring how the interaction between resources and institutions shapes and constrains the effects of interest groups in global governance.

\section{Resource configurations, institutional arrangements, and mission pressures}

Resource configurations are core determinants of INGO strategy. A rich literature on nonprofit management looks at how funding sources, organizational culture, and other managerial practices enable NGOs to act efficiently and achieve their stated goals. The ways NGOs structure their relationships with their boards (Renz 2004), ethically manage donations (Kerlin 2006), train employees and volunteers (Watson and Abzug 2010), increase their geographic reach through franchises and branches (Oster 1992), or work with local partners (Stiles 2002) all have direct bearing on organizational effectiveness. Importantly, however, there is no ideal configuration of resources. Herman and Renz (2004) show that practices that enhance effectiveness in one NGO will not directly translate to practices in another organization. Similarly, the pursuit of one type of resource over others can place organizational strategy at risk. Consistent funding is essential, but the pursuit of different sources of money can reshape organizational priorities and lead to mission drift (AbouAssi 2013). Collaboration with other NGOs can expand organizational capacity, but it can also lead to mission drift or suppress less popular social objectives (Pallas and Nguyen 2018; Witesman and Heiss 2016). Rather than adhere to a set of universal best practices, NGOs that ensure their current configuration of resources aligns with their core values and mission are better able to reach their advocacy goals and affect policy change.

INGO resource configurations are shaped in part by institutional constraints, including the legal regulations, political trends, and cultural norms of home and target countries (Heiss and Johnson 2016). In contrast with resource configurations, the effect of institutions on INGOs is relatively understudied (Bloodgood, TremblayBoire, and Prakash 2014). Stroup (2012) shows that the organizational structures and missions of INGOs are deeply tied to the cultural and legal environments of their home countries. Newer work has turned to the influences of target country institutions on INGOs. International advocacy organizations often engage in geographic forum shopping, establishing offices in countries with the most amenable institutional arrangements in repressive regions, or building the 'best house in a bad neighborhood' (Barry et al. 2015). INGO access to advocacy venues is also shaped by institutional factors. Henry et al. (this special issue) demonstrate how 
both home-country political institutions and international organization norms determine NGO participation in global governance institutions. Table 1 provides a list of general examples of organizational and institutional characteristics. INGOs typically have direct control over their resource configurations and strive to align their resources with their missions. Organizations have less control over institutional constraints, but will still seek out favorable donors, legal environments, and target countries.

Table 1: Resource configurations and institutional constraints

\begin{tabular}{ll}
\hline Examples of elements of resource configurations & Examples of institutional constraints \\
\hline Predictable and consistent revenue & - Donor demands and expectations \\
- Highly trained managers, staff, and volunteers & - Target country regime's perception of contentiousness of \\
- Carefully managed organizational structure & INGO programming \\
- Careful board oversight & - Legal environment and regulations in target country \\
- Geographic reach & - Political trends in target country \\
- Collaborative relationships with other organizations & - Accessibility of neighboring countries \\
- Staff with local connections & \\
\hline
\end{tabular}

The interaction between resources and institutions influences organizational strategy and can make it difficult to achieve advocacy objectives. Institutional pressures from donors and governments can encourage INGOs to change their missions and create inefficiencies in programming (Heiss and Kelley 2017). Government grants can crowd out and replace private donations and strict reporting requirements can shift organizational priorities towards bureaucratic compliance and away from their core missions (Bush 2015; Kim and Van Ryzin 2014).

Target country institutional dynamics also impose pressures to shift mission strategies. Repressive governments attempt to limit the foreign influence of guest INGOs and mitigate their potential political risks while simultaneously reaping benefits from their expertise and money (Heiss 2019). The relationship between governments and INGOs is defined largely by the contentiousness of INGO programming and how well it aligns with regime preferences. Organizations working on issues that correspond to less contentious issues like disaster relief or education face less regulatory pressure than organizations working on more threatening issues like human rights. Governments reduce the risks of contentious INGOs through regulations that are designed to create a less tolerant institutional environment for INGOs and to encourage changes in programming in order to remain active in the country (Heiss 2017). 


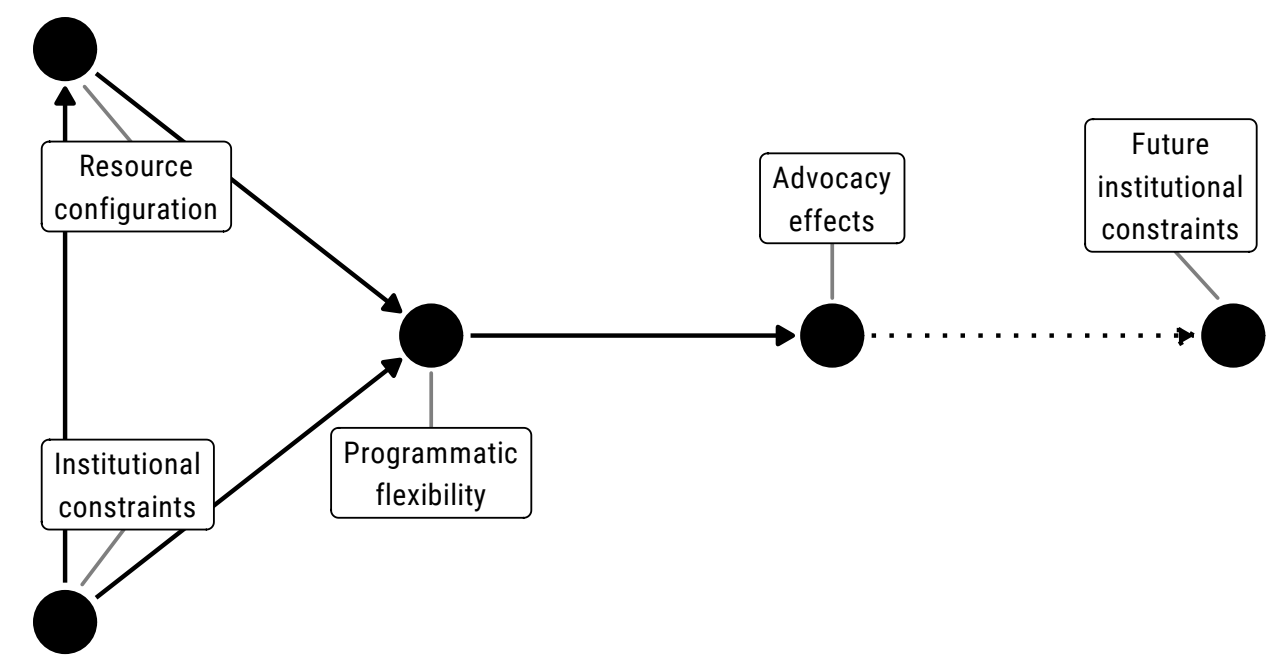

Figure 1: Relationship between institutional constraints, resource configurations, programmatic flexibility, and advocacy effects

\section{Programmatic flexibility}

Advocacy INGOs thus face natural pressure to change their core missions and strategies as they pursue better resource configurations or confront restrictive institutional constraints. What enables these organizations to cope with regulations and have advocacy effects in their target countries without losing focus on their missions? Moreover, what allows organizations to then reshape those institutional constraints? I theorize that the interplay of organizational resource configurations within target country institutional constraints creates programmatic flexibility that allows INGOs to adapt to their institutional environment without losing mission focus (see Figure 1). This flexibility enables organizations to overcome legal barriers and succeed in having advocacy effects, which in turn allows organizations to influence the future institutional and legal constraints of their target countries and potentially take control of the regulations they face.

Resources and constraints each act semi-independently in shaping an organization's flexibility and enabling it to achieve its advocacy goals. An organization with consistent revenue streams, trained professional staff, strategic alignment with donor expectations, collaborative relationships with other advocacy groups, and access to multiple countries through a network of regional offices can be said to have a positive resource configuration, which in turn provides it with a degree of programmatic flexibility. Organizations with a negative resource configuration, in 
contrast, might be underfunded, work within a limited geographic scope, or engage in poor managerial practices.

Resources alone do not determine an organization's flexibility. An organization that faces a favorable legal environment and engages in non-contentious programming has positive institutional constraints. Even if such an organization is managed poorly or struggles to attract donors or funding, it will still be able to be more flexible in the implementation of its programs. Organizations working on more contentious issues in countries with harsh legal restrictions that prohibit advocacy, on the other hand, face negative institutional constraints and are naturally more limited in the strategies they can undertake. Under these constrained institutional conditions, organizations must rely on more positive resource configurations to maintain their programmatic flexibility and achieve their advocacy goals. At the same time, institutional constraints - such as a regime's perception of an INGO's contentiousness - can directly shape INGO resource configurations. For instance, ongoing research shows that donor states withdraw funding for overseas NGOs in the wake of regulatory crackdown (Chaudhry and Heiss 2019).

The interaction between resources and constraints creates programmatic flexibility. If constraints are permissive enough or if an INGO has sufficient resources, it will have the flexibility to make adjustments without shifting its mission. Advocacy groups with high levels of programmatic flexibility are in the best position to overcome constrained institutional arrangements, maintain access to their target countries, achieve their desired advocacy goals, and influence policy domestically and globally. If an organization enjoys consistent revenue, it can better cope with inevitable losses in revenue following passage of laws banning foreign funding. If an organization establishes offices in countries near more restrictive states, it can shift staff and resources out of a country when facing legal crackdown while continuing its work throughout the region. Organizations with low levels of flexibility, on the other hand, are unable to quickly cope with shifts in target-country institutional arrangements and subsequently lose access to or are banned from those countries, and thus fail to have advocacy effects.

I illustrate this argument with two case studies of INGOs with varying resource configurations, target country institutional constraints, and programmatic flexibility. The experiences of Article 19, a prominent freedom of expression advocacy INGO, and AMERA International, an INGO advocating for refugee rights in the Middle East and Africa, demonstrate how flexibility permits organizations to attain their desired advocacy goals and potentially reshape their institutional constraints. Both organizations work in the Middle East and face similar legal restrictions, but with diverging outcomes. Despite its contentious programming, Article 19 has been resilient in the face of authoritarian restrictions in its target countries and its programmatic flexibility has enabled it to reshape domestic policy in Tunisia and else- 
where. AMERA, on the other hand, enjoyed a cooperative relationship with Egyptian government officials as it provided services and engaged in advocacy that was non-threatening to the regime. However, as civic space constricted following the 2011 Arab Spring, AMERA's inflexibility forced it to withdraw from the country.

I draw on evidence from these organizations' published materials and annual reports, as well as in-person interviews with senior staff. As these interviews were performed as part of a larger project on INGO responses to authoritarian restrictions, participants were guaranteed anonymity. In each case, I identify the resource configurations and institutional constraints that determine each organization's level of programmatic flexibility. I then trace how each either drew on this flexibility to overcome restrictions, reshape domestic regulations, and strengthen global governance norms, or failed to respond to changes in regulations and subsequently exited the country. Importantly, I do not engage in hypothesis testing. There is too much variation in resource configurations and institutional constraints within each of these cases to isolate their influence on programmatic flexibility and advocacy effects. These cases do, however, usefully illustrate the role of flexibility in achieving advocacy goals and potentially taking control of regulatory environments.

\section{Article 19}

Article 19 takes its name from the nineteenth article of the UN's Universal Declaration of Human Rights, which establishes the right to freedom of opinion and expression. The organization's stated mission is to 'work so that people everywhere can express themselves freely, access information and enjoy freedom of the press'. ${ }^{1}$ To promote individual expression the organization publishes research papers, issues statements, and releases advocacy letters that discourage repressive regimes from passing laws to abrogate assembly and speech rights. Article 19 also works directly with local lawyers to defend the rights of people imprisoned for self-expression and lobbies and advises politicians and bureaucrats as they draft new laws to regulate expression. To ensure access to information, Article 19 lobbies governments for Right to Information (RTI) laws that guarantee access to public information and promote government transparency and accountability. Article 19 has had substantial effects in both global governance structures and in its target countries' policies, shaping international standards for freedom of expression and working directly with dozens of governments to establish and reform domestic laws, including Serbia, Uganda, Macedonia, and Tunisia (Berliner 2016; Landman and Abraham 2004, 32).

1. Article 19, 'Mission', https://www.article19.org/pages/en/mission.html, accessed August 2, 2017. 


\section{Resource configurations}

Like other contentious foreign advocacy NGOs, Article 19 has been stymied by anticivil society laws in many of the countries it lobbies, including Egypt, Russia, China, Azerbaijan. These laws, such as Russia's 2012 Foreign Agent Law, are designed to prevent domestic NGOs with ties to foreign sponsors from obtaining funding from abroad and to limit access to foreign INGOs. However, Article 19 has adapted to and circumvented many of these restrictions by relying on positive resource configurations: steady streams of revenue that keep the organization afloat, partially decentralized managerial structures that provide it with global reach, and collaborative relationships with other NGOs and governments that expand its ability to lobby.

Steady revenue The bulk of Article 19's funding comes from governments and private foundations. Roughly half its income comes from British government agencies (Stroup 2012, 180), including the Foreign and Commonwealth Office, the Department for International Development (DFID), and embassies. The remainder comes from other foreign governments, primarily Sweden and Norway, the European Commission, and American foundations, including the Open Society Foundations (OSF) and the National Endowment for Democracy (NED). Article 19 has maintained a steady flow of revenue over time, shifting and seeking out new grants as needed. For instance, after funding from the Open Society Foundations dried up in 2004, the organization replaced the shortfall with grants from the Ford Foundation. In general, the organization has maintained a balanced or surplus budget, which has allowed it to expand its operations to a global scale (see top panel of Figure 2).

Geography Since the early 2ooos, Article 19 has divided its advocacy work by region, assigning staff to portfolios of countries in Africa, Asia, Europe, Latin America, and the Middle East and North Africa, each overseen by an expert program officer. The organization also maintains issue-specific programs focused on law, operations, and digital advocacy, covering its work across all regions. Prior to 2005, beyond a few small regional offices in Latin America, most of Article 19's staff were based in London, with program officers traveling regularly to their assigned regions and communicating with implementing partners remotely. In 2007, the organization declared that it would establish some sort of physical presence on every continent, including the 'posting of staff, opening of local/regional offices, and/or institutionalised partnership (franchise) with local NGOs' (Article 19 2008, 18). Today Article 19 has a nearly global reach (see Figure 3). Each local office is governed by its own board of directors that is charged with implementing the programs and strategy organized and proposed by the central London office. 

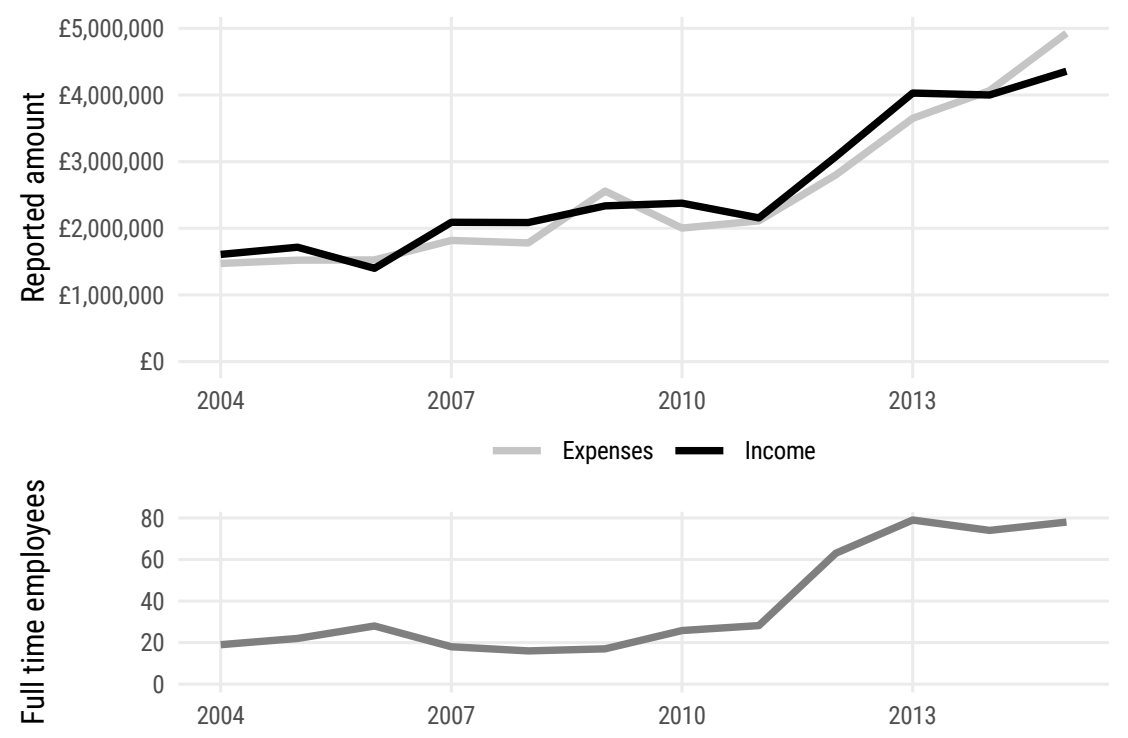

Figure 2: Article 19's income, expenditures, and full-time staff, 2004-15

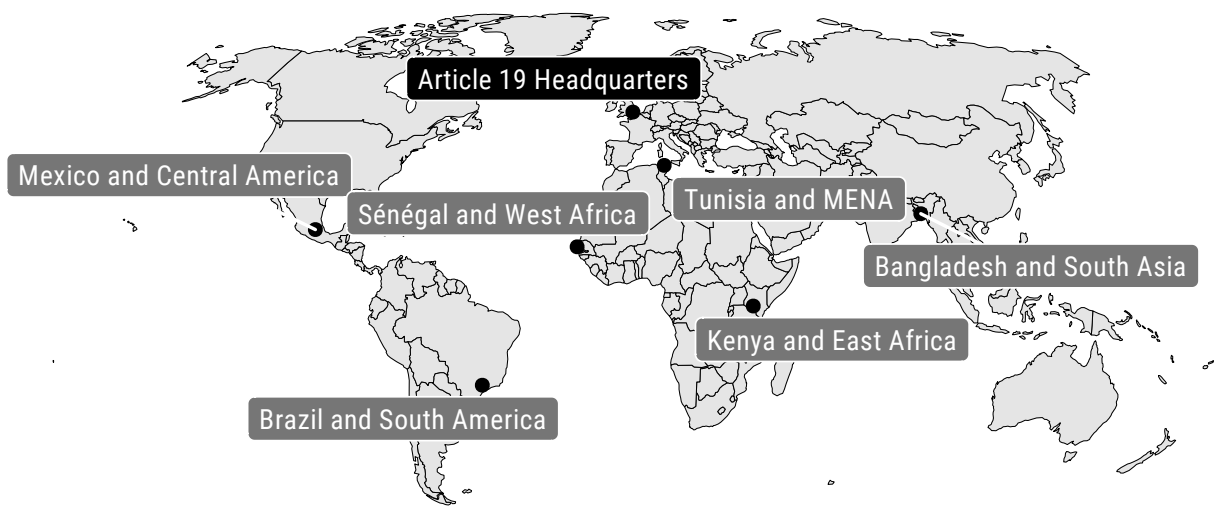

Figure 3: Article 19's headquarters and regional offices 
Article 19's focus on global advocacy was made possible because of this new network of regional and national offices. Between 2011-13, in conjunction with its goal of reaching every continent, the organization quadrupled its number of full-time employees (see bottom panel of Figure 2) and spread its new staff to its regional offices. This global reach gives the organization increased access to government officials, enhances its lobbying ability, and allows it to stay abreast of regulatory changes. Most importantly, this network provides a safe home in restricted regions (Barry et al. 2015), which in turn allows it to shift resources and programs around as institutional environments constrict. For instance, as legal environments for civil society worsened in Libya and Egypt, Article 19 could cut back on some of its programming while continuing to have a Middle Eastern presence with its office in Tunisia. The organization made similar regional shifts in East Africa, maintaining its headquarters in Kenya as anti-civil society laws were passed in Ethiopia and Sudan. Article 19 remains involved in these closed countries by maintaining regional toeholds in countries with more open regulations. ${ }^{2}$

Collaboration Finally, Article 19 maintains close relationships with more than 9o different governments, IGOs, and INGOs, ${ }^{3}$ and was a founding member of the International Freedom of Expression Exchange (IFEX), a global network of advocacy NGOs. Today, IFEX boasts more than 100 organizational members, including prominent human rights organizations like the Electronic Frontier Foundation, Human Rights Watch, Reporters without Borders, and PEN International. ${ }^{4}$ Participation in issue networks like IFEX boosts Article 19's lobbying and litigation capacity and grants access to countries and resources that are closed off due to strict regulations. Article 19 continues to issue legal analyses and censorious press releases about repression in Russia because it shares information with IFEX members who still have access to the country, like the Russia-based Mass Media Defence Centre. ${ }^{5}$

\section{Confronting restrictions with programmatic flexibility}

Moving strategic planning and implementation away from Article 19's central offices in London was designed to enhance the organization's access to remote partners, allowing it to 'respond more swiftly to opportunities or crises, ... be closer to

2. Interview 1056, October 13, 2016, London.

3. Article 19, 'What we do', https://www.article19.org/pages/en/what-we-do.html, accessed August 2, 2017.

4. IFEX, 'Our Network', https://www.ifex.org/our_network/, accessed August 2, 2017..

5. Article 19, 'Russia: 50+ international and Russian NGOs contemn Telegram block and Russia's assault on Internet freedom,' https://www.article19.org/resources/russia-international-andrussian-ngos-condemn-telegram-block-and-russias-assault-on-freedom-of-expression-online/, accessed September 29, 2018. 
[its] partners, work more closely with them, and thus be more capable to respond to their demands and strengthen interactions and capacities' (Article 19 2009, 38). Beyond extending the organization's global reach by moving its experts to the field, decentralization also provided legal and regulatory benefits and allowed Article 19's central offices to better handle the complexities of each country's registration regulations. These offices were formally registered according to each country's foreign NGO regulations, and to smooth the registration process and work around regulations, each office was established as part of projects funded by large donors. Article 19 Mexico, for example, was created in 2008 as part of an RTI advocacy campaign - its local registration was incidental to the overall program. Other regional offices followed a similar pattern: Article 19 Brazil and Article 19 Bangladesh were both incorporated in 2008 while implementing RTI programs funded by DFID, while Article 19 Kenya was registered in 2007 to undertake a project in Sudan funded by the European Commission and the Norwegian Ministry of Foreign Affairs (Article 192009,38 ). Article 19 collaborated with its funders to overcome and avoid registration hurdles. Not only did bundling the registration of its regional offices with larger grants sponsored by governmental aid agencies expedite the registration process in each country, linking registration to grant fulfillment imbued Article 19's regional offices and programs with international legitimacy.

Article 19 further ensured the success of their remote registration by strategically selecting countries with the most amenable legal environments. In the past decade, the organization has considered establishing a more formal presence in countries like Egypt and China, but concluded that the regulatory environments for INGOs in these countries would require too many legal resources to keep any offices open. ${ }^{6}$ When deciding where to expand its regional offices, Article 19 selects countries where it can have the most impact - both in-country and throughout the region - with the least amount of government interference. For instance, the organization has offices in Bangladesh, Kenya, and Tunisia, which have more relaxed registration laws than their regional neighbors like India, Ethiopia, or Egypt. The organization formally registered its office in Tunisia in 2011 precisely because it was the 'safe option'.7 Because post-revolutionary laws regarding NGO registration were more open than any other country in the region, Tunisia became a safe central home base for Article 19's Middle Eastern programming.

Article 19 can afford to be selective in where it places its regional offices because of its programmatic flexibility. Since it already has an established headquarters in London, it can take time to deliberate and debate possible regional offices. With steady revenue, it can take more risks regarding program expansion. Additionally,

6. Interview 1056, October 13, 2016, London.

7. Interview 1056, October 13, 2016, London. 
because it has multiple programs spread across the world, the organization can more easily close and relocate its offices. In the 1990s, prior to the Article 19's official policy of decentralization, it incorporated Article 19 South Africa as a regional subsidiary organization. Rising operational costs and increasing difficulties with coordination led to the office's closure in 2004 (Stroup 2012, 18o; Article 19 2005b), but leaving the country did not end the organization's regional programming. From its base in London, the organization continued to hold workshops, lobby politicians, consult bureaucrats, and litigate against censorship throughout the region (Article 19 2005a, 2006).

\section{Drawing on programmatic flexibility to shape regulations}

When working in countries with restricted civic space, Article 19 bundles issues of expression and assembly to lobby for both simultaneously, arguing that 'the defence of freedom of expression and access to information is essentially the defence of civic space' (Article 19 2015, 8). This, in turn, has powerful knock-on effects: improving the legal environment in one country allows the organization to maintain its access throughout the region and have advocacy effects on global expression and associational laws.

Tunisia provides a prime example of how the organization's resource configuration allows it to overcome restrictions and influence policy and regulations. Article 19 began working in the country in 2005 as part of the Tunisia Monitoring Group (IFEX-TMG), a special eight-year endeavor organized by IFEX. Working with regional and international partners such as the Arabic Network for Human Rights Information, Index on Censorship, Freedom House, and the Egyptian Organization for Human Rights, IFEX-TMG sent regular fact-finding and consulting missions to Tunisia, culminating in multiple reports outlining legislative recommendations to enhance media freedom, end censorship, and improve the rights of association, assembly, and movement (IFEX-TMG 2005, 2010). Under President Ben Ali's rule, few recommendations were likely to be implemented. However, following the president's overthrow during the 2011 Arab Spring, Article 19 was ideally positioned to influence human rights policy in the country and opened a formal regional office in Tunis. Building on relationships established during IFEX-TMG missions, newly-elected Tunisian politicians solicited technical advice from Article 19 on issues related to freedom of expression and human rights more generally. The organization held workshops for legislators, offered regular comments on the nascent constitution, and worked with the president and party chairs to ensure that the legal environment for speech and assembly in the newly democratizing country would be safe and inviting (Article 19 2013). In January 2014, the country's National Constituent Assembly (NCA) adopted a new constitution that generally 
accorded with international human rights standards. Prominent politicians cited Article 19's assistance throughout the drafting process, including interim president Moncef Marzouki and NCA president Mustapha Ben Jafar (Article 19 2015, 16).

Despite these new constitutional protections, subsequent governments have continued to infringe on expression rights. However, secure in its legal status, Article 19 has been able to continue its work in Tunisia, issuing 87 advocacy letters and statements since the fall of Ben Ali in 2011, condemning government abuses, censorship, and arrests of journalists and activists. The organization's close connections with local politicians - as well as the more permissive legal environment for advocacy in general - allow Article 19 to continue its mission and litigate against the government.

Additionally, Article 19 has been able to use Tunisia as a regional home base. Egypt, Syria, Bahrain, and other Middle Eastern countries have imposed strict INGO regulations, either by preventing registration or by passing laws that make human rights advocacy illegal. To get around these restrictions, Article 19 brings regional activists to its Tunisia office for training and research, rather than sending staff to those more restrictive countries. ${ }^{8}$ Accordingly, despite closed and dangerous civic space, Article 19 has been able to continue its post-Arab Spring advocacy, issuing reports and policy briefs to countries throughout the region.

Laws impeding Article 19's work in the Middle East are generally designed to make operating an INGO abroad more difficult and costly. Article 19 has adapted to these increasingly onerous regulations and continued its advocacy by relying on its programmatic flexibility. Collaboration with IFEX-TMG, politicians, and local NGOs in the years prior to the revolution, consistent government- and foundationbased funding, and highly trained staff allowed Article 19 to rapidly establish an office in 2011 and have positioned the organization to remain active in the region. Within the more favorable institutional conditions in Tunisia, this configuration of resources provided the organization with substantial flexibility in continuing its operations throughout the region - thus ensuring advocacy effects - and in shaping future institutional constraints, creating a more favorable operating environment in Tunisia.

\section{AMERA}

Article 19's reserves of programmatic flexibility, fueled by a positive resource configuration and a favorable institutional environment in Tunisia, enabled it to circumvent regulations, maintain an antagonistic relationship with its target countries, and ultimately reshape regulations to be more favorable when needed. The

8. Interview 1056, October 13, 2016, London. 
case of Africa and Middle East Refugee Assistance (AMERA) ${ }^{9}$ International, in contrast, demonstrates how sudden changes in a target country's institutional arrangements can pose challenges to advocacy groups low in flexibility. AMERA was an international advocacy NGO that provided legal services for refugees in Egypt and lobbied for improved refugee policies throughout the region. Driven by the belief that 'legal aid ... is the right of all refugees', ${ }^{10}$ AMERA's mission was to 'provide pro bono legal aid for refugees in countries where such services are non-existent or limited and where legal representation might assist them in actualizing their rights' ${ }^{11}$ Since its incorporation in 2003, AMERA has provided a variety of programs, including pro bono litigation and advocacy, refugee status determination, social support for survivors of human trafficking and sex- and gender-based violence, resettlement assistance, and assistance for unaccompanied minors.

\section{Resource configurations}

AMERA benefitted from multiple positive resource configurations, including welltrained staff and close collaborative relationships with similar refugee rights organizations, but its irregular and uncertain revenue, combined with a constricting legal environment in Egypt, hampered its programmatic flexibility despite its less non-contentious programming and its friendly relationship with the government. Consequently, it was unable to exert advocacy effects on the Egyptian government and reshape refugee or civil society regulations.

Staff with local connections AMERA had a small, highly experienced staff, ranging from 20-30 full-time employees between 2004 and 2013, split between its UK and Egypt offices (see bottom panel of Figure 4 ) ${ }^{12}$ The organization also relied on volunteer interns to help with paralegal, administrative, and translation work. Staff and volunteers were diverse, well-trained, and fit the needs of the organization's constituents, providing AMERA with the necessary language skills, legal expertise, psychologists, and community outreach to provide legal aid and representation to nearly 1,40o clients (AMERA UK 2011, 3). Egyptians on staff gave AMERA resources

9. As described below, there is a legal distinction between AMERA UK, AMERA Egypt, and AMERA International. For the sake of narrative simplicity, I refer to the organization as AMERA unless describing something specific to the organization's operations in the UK or Egypt.

10. AMERA UK, 'Objectives and History', https://web.archive.org/web/20130820091141/http:// amera-uk.org/index.php/who-we-are/objectives-a-history, accessed August 2, 2017.

11. AMERA International, 'Background', http://www.amerainternational.org/background/, accessed August 2, 2017; AMERA International, 'Who We Are', http://www.amerainternational.org/ who-we-are/, accessed August 2, 2017.

12. AMERA's fiscal year ends on January 31 of the following year. To align its financial reports with a January-December calendar year, I shift all reported numbers back one year. Thus, financial figures for the year ending on January 31, 2009 are marked as 2008. 

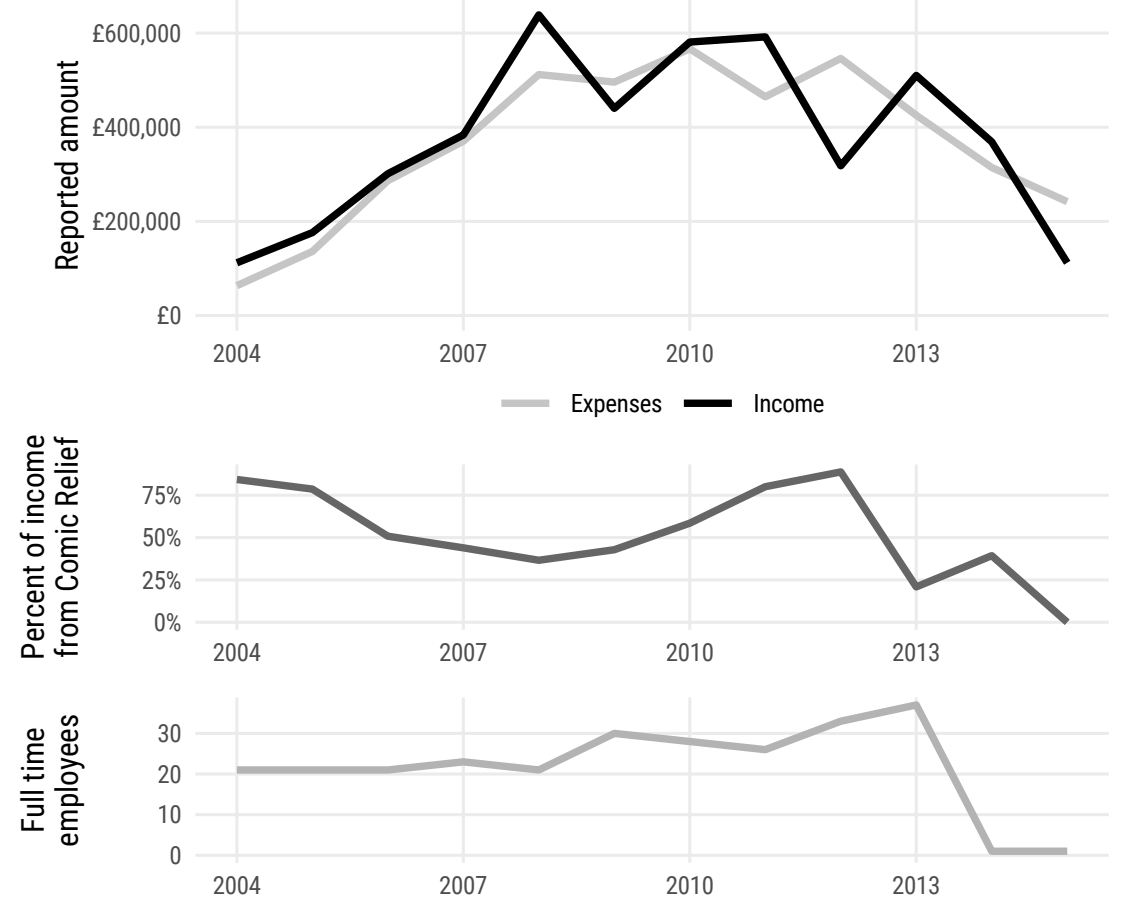

Figure 4: AMERA's income, expenditures, and full-time staff, 2004-15

to confront the changing legal environment, while staff and volunteers from Sudan, Somalia, Ethiopia, and Eritrea allowed the organization to maximize its contacts in the refugee community in Cairo.

Geography Unlike Article 19, which operates in dozens of countries through its home and regional offices, AMERA did not enjoy wide geographic reach (see Figure 5). AMERA's refugee assistance required direct one-on-one legal advocacy on the ground, thus the organization was naturally limited in their geographic scope. AMERA UK was created to be an overarching international umbrella organization for assisting with refugee rights and advocacy throughout the global south (AMERA UK 2008, 3), and the organization began with regional headquarters in Egypt and a pilot refugee law program in Uganda. AMERA's work in Uganda was an early success, and its pilot program was soon spun off into an independent NGO. ${ }^{13}$ In 2012, AMERA UK identified and began working with new partners in Morocco (Droit et Justice) and Cameroon (Refugee Welfare Association Cameroon) (AMERA UK

13. AMERA's fundraising commitments for this spinoff ended in 2013 (AMERA UK 2014) 


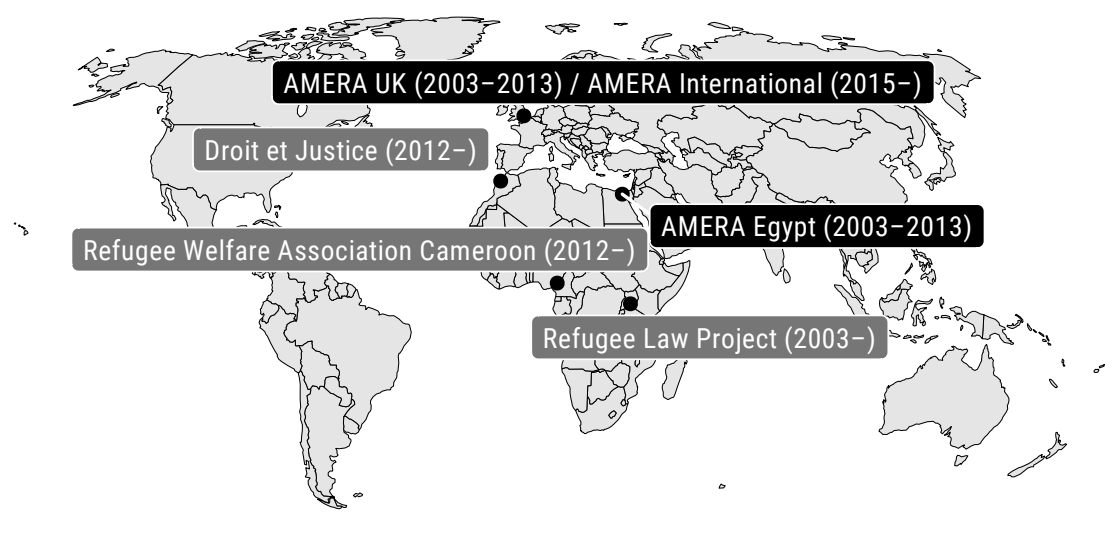

Figure 5: AMERA's offices and primary partners

2013), but due to budget crises and legal challenges in Egypt, expansion was slow. Moving its programs between countries that impose legal restrictions was not an effective response to legal crackdowns.

Collaboration AMERA cultivated partnerships with refugee and human rights organizations from its headquarters in Egypt, including the Egyptian Foundation for Refugee Rights, Caritas, the International Committee of the Red Cross (ICRC), St. Andrews Refugee Services, Catholic Relief Services, and the El Nadeem Center for Psychological Rehabilitation of Victims of Violence and Torture. In partnering with these organizations, AMERA Egypt was able to connect refugees with additional psychological, financial, and legal support, as well as shelter, food, family reunion services, education, and medical care. More importantly, this collaboration put AMERA at the center of a growing network of refugee-related NGOs in Cairo (AMERA UK 2014, 2), a position that later proved instrumental for continued service provision after the organization left the country.

Unsteady revenue AMERA's most significant obstacle was its inconsistent and unpredictable revenue (see Figure 4). Since its inception, the organization received the majority of its funding from donations from Comic Relief, a UK-based nonprofit that raises money through annual comedy broadcasts. As seen in the middle panel of Figure 4, grants from Comic Relief accounted for 85\% of AMERA's income in 2004 and between 50-90\% of the organization's revenue thereafter. Comic Relief funding dropped in 2013, just as AMERA Egypt faced the most regulatory pressure, and by 2015 the two organizations' partnership ended. 
Recognizing its lack of income diversification, in 2007 AMERA UK hired a new executive director tasked with stabilizing the organization's revenue (AMERA UK 2009, 2). The organization received grants from the Sigrid Rausing Trust, the Amberstone Trust, the Ford Foundation, and the US State Department and Swiss and US embassies in Cairo. AMERA's income peaked at more than 1600,000 in 2008 , but in subsequent years the organization slowly lost its foundation and government funding, and by 2015 it was funded exclusively by a grant from the State Department and $\mathfrak{f}_{5}, \mathrm{ooo}$ in private donations. The loss of funding from Comic Relief and the inability to maintain regular foundation and government funding put AMERA in a precarious situation as it confronted legal and safety challenges in Egypt.

\section{Succumbing to restrictions and shutting down}

AMERA's most challenging legal obstacle - and the issue that led to its withdrawal from Egypt - was its inability to formally register as a civil society organization, which in turn posed a threat to its safety and continued operations. Unlike AMERA's Refugee Law Project in Uganda, AMERA Egypt did not become fully independent.

Prior to the 2011 Arab Spring, advocacy organizations in Egypt were regulated by Law 84 of 2002, which required that all civil society organizations be registered with the Ministry of Foreign Affairs. In practice, however, Egyptian officials enforced this law with great discretion and many NGOs did not register. AMERA UK began the process of registering AMERA Egypt as its official branch in Cairo in 2010, having already worked in the country for several years (AMERA UK 2011, 3). One director noted that ' $\mathrm{b}] \mathrm{b}$ ecause we were doing what the government was happy to have done, the government tolerated us', ${ }^{14}$ despite the lack of official registration. AMERA Egypt partnered with a local law firm that provided pro bono legal support for the registration process (AMERA UK 2012, 7), and waited for its application to wind through the Egyptian bureaucracy.

In 2011, however, the institutional environment for all INGOs working in Egypt changed dramatically. Initially, the organization's primary concern was safety, as protests leaned towards violence in the months following Hosni Mubarak's resignation. AMERA Egypt periodically shut down its main offices during the worst political unrest, and staff met with clients offsite to continue the organization's work with as few interruptions as possible (AMERA UK 2012, 2). Despite the turbulence, AMERA continued to assist with asylum applications, legal consulting, and victim counseling, while its UK trustees began to set aside reserves to ensure that the organization could 'meet the costs of closure or wind-down' if circumstances warranted

14. Interview 1036, August 17, 2016. 
it (AMERA UK 2012, 5). The registration application with the Ministry of Foreign Affairs stalled amidst the political upheaval.

Beginning in 2012, the legal landscape shifted again, as post-revolutionary governments proposed draft legislation designed to severely restrict advocacy organizations with foreign connections. AMERA continued its work through 2012 and 2013, but a large influx of refugees from Syria and a dramatic drop in revenue combined with an increasingly restricted regulatory environment to put incredible pressure on the organization. AMERA Egypt increasingly relied on assistance from its partners, working with ten other advocacy organizations to supplement their services. AMERA's registration application remained in flux as members of parliament debated the draft anti-NGO legislation. Without formal registration, AMERA Egypt would not be able to obtain permission to receive funding from AMERA UK, and the organization would shut down.

The relationship between AMERA Egypt and the Egyptian government remained mostly amicable - police never raided their offices, detained staff, or confiscated resources. Every time the organization communicated with its partners at the Ministry of Foreign Affairs, they were told that the application was in order, but final approval never arrived and their registration status was perpetually pending. In 2013, AMERA UK worried that the détente would soon come to an end. The Ministry had upped its pressure on INGOs and state security forces regularly raided local NGOs receiving foreign funding. By the end of 2013, AMERA UK 'saw the handwriting on the wall', assumed that its legal status would never be secured, and began the process of transferring the operations of AMERA Egypt to the Egyptian Foundation for Refugee Rights (EFRR). ${ }^{15}$

In 2014, AMERA UK closed AMERA Egypt, temporarily reincorporated as the International Refugee Rights Initiative (IRRI) in the UK (IRRI 2015), and continued to send grants to EFRR, though with little input into the management of its programs. In October 2014, EFRR took full control over all programs and in 2015, IRRI completed its drawdown from Egypt, changed its name to AMERA International, and slowly began to expand its fundraising and training activities in Morocco and Cameroon (AMERA International 2015).

The combination of reduced resources - particularly the organization's decline in funding - and the prospect of worsening institutional constraints through proposed civil society restrictions left AMERA with little programmatic flexibility. While AMERA Egypt's strong relationships with the Cairene refugee community and local politicians and bureaucrats put AMERA in a position to lobby for improved refugee and advocacy laws, it was unable to do so and ultimately left the country.

15. Interview 1036, August 17, 2016. 


\section{Conclusion}

According to nonprofit management research, it is not surprising Article 19 - a larger, well-funded, and better geographically positioned organization - was able to achieve its advocacy goals and adapt to changing regulations while AMERA was not. By incorporating the notion of programmatic flexibility, though, we find a more complex relationship between resources and advocacy effects and uncover fruitful connections between INGO and interest group research. Institutional constraints mediate an organization's resources and shape its ability to both configure its resources and find flexibility. This flexibility then allows INGOs to engage in advocacy, and under the right conditions, influence their regulatory environments. These cases combine disparate interest group, nonprofit management, and international relations literatures into one unified theory and pave the way for more rigorous analysis of the individual components of Figure 1.

The interaction between internal resource configurations and the external institutional arrangements in their target countries shaped Article 19 and AMERA's strategies and potential for having effects on domestic and global policy. A key factor in these organizations' disparate outcomes is programmatic flexibility. Endowed with reliable funding, longstanding relationships with government officials, and deep connections with local partners and larger networks of other advocacy organizations, Article 19 engaged in geographic venue shopping, overcame Tunisian regulations, reshaped its legal environment, and maintained the contentiousness of its mission in Tunisia and throughout the region. AMERA's departure from Egypt, on the other hand, occurred not only because the institutional environment worsened, but because it lacked sufficient programmatic flexibility to cope with changing regulations. In the face of regulatory, organizational, and financial uncertainty, the organization ceased its advocacy work and left the country.

These findings also raise important questions and caveats. Is there a threshold of institutional arrangements that makes a country more amenable to advocacy group work and that allows INGOs to have policy effects? Article 19 purposely avoided using Egypt as its regional home - instead it chose the country with the most manageable regulatory environment. What determines when a country becomes more or less attractive to advocacy organizations shopping for a new headquarters?

Similarly, does a specific combination of resource configurations allow organizations to adapt to regulations? Would the outcomes of the cases have been different had Article 19 lost the bulk of its funding or if AMERA had a wider network of permanent offices throughout the region that could have absorbed its Egypt office? Relatedly, configurations of resources may interact differently depending on institutional context, thus reshaping programmatic flexibility. For INGOs working in countries that ban funding from foreign donors, reliance on deep-pocketed foreign 
donors can be a liability. Even if laws do not prohibit foreign funding, INGOs working in countries that are antagonistic to their main donors (e.g. accepting USAID grants while working in Russia or Central Asia) will limit programmatic flexibility and force organizations to rely on other resource configurations.

Though these questions remain unanswered in this paper, they pave the way for exciting research agendas that continue to combine theories of resource configurations and institutional arrangements in international advocacy and global governance.

\section{Conflict of interest statement}

The corresponding author states that there is no conflict of interest.

\section{References}

AbouAssi, Khaldoun. 2013. "Hands in the Pockets of Mercurial Donors: NGO Response to Shifting Funding Priorities." Nonprofit and Voluntary Sector Quarterly 42 (3): 584-602. doi:10.1177/0899764 012439629.

AMERA International. 2015. Report of the Trustees and Unaudited Financial Statements for the Year Ended 31 fanuary 2016. Reading, UK.

AMERA UK. 2008. Reports and Accounts for the Year Ended 31 fanuary 2008. Reading, UK.

. 2009. Reports and Accounts for the Year Ended 31 January 2009. Reading, UK.

- 2011. Reports and Accounts for the Year Ended 31 fanuary 2011. Reading, UK.

2012. Reports and Accounts for the Year Ended 31 fanuary 2012. Reading, UK.

- 2013. Reports and Accounts for the Year Ended 31 fanuary 2013. Reading, UK. . 2014. Reports and Accounts for the Year Ended 31 Fanuary 2014. Reading, UK.

Article 19. 2005a. Annual Review 2004. London.

- 2005b. Report and Consolidated Financial Statements for the Year Ended 31st December 2004. London, September 2.

. 2006. 2005 Annual Implementation Report. London.

. 2008. 2007 Annual Report. London, July.

- 2009. 2008 Annual Report. London, July.

- 2013. Implementation Report for 2012. London. 2015. Protecting Civic Space: Annual Report 2014. London.

Barry, Colin M., Sam Bell, K. Chad Clay, Michael E. Flynn, and Amanda Murdie. 2015. "Choosing the Best House in a Bad Neighborhood: Location Strategies of Human Rights INGOs in the NonWestern World." International Studies Quarterly 59, no. 1 (March): 86-98. doi:10.1111/isqu.12172.

Berliner, Daniel. 2016. "Transnational Advocacy and Domestic Law: International NGOs and the Design of Freedom of Information Laws.” Review of International Organizations 11, no. 1 (March): 121-44. doi:10.1007/s11558-015-9228-6.

Bloodgood, Elizabeth A., Joannie Tremblay-Boire, and Aseem Prakash. 2014. "National Styles of NGO Regulation.” Nonprofit and Voluntary Sector Quarterly 43 (4): 716-36. doi:10.1177/0899764013481111.

Bush, Sarah Sunn. 2015. The Taming of Democracy Assistance: Why Democracy Promotion Does Not Confront Dictators. Cambridge, UK: Cambridge University Press. doi:10.1017/cbo9781107706934. 
Chaudhry, Suparna, and Andrew Heiss. 2019. Charity During Crackdown: Analyzing the Impact of State Repression of NGOs on Philanthropy. Working paper.

CIVICUS. 2017. People Power Under Attack: Findings from the CIVICUS Monitor. April.

Dellmuth, Lisa M., and Elizabeth A. Bloodgood. this special issue. Advocacy Groups in Global Governance: Global and Domestic Opportunity Structures. Working Paper.

Dellmuth, Lisa M., and Jonas Tallberg. 2017. "Advocacy Strategies in Global Governance: Inside vs. Outside Lobbying.” Political Studies 65, no. 3 (October): 705-23. doi:10.1177/0032321716684356.

Heiss, Andrew. 2017. "Amicable Contempt: The Strategic Balance between Dictators and International NGOs.” PhD diss., Duke University.

- 2019. "NGOs and Authoritarianism." In Routledge Handbook of NGOs and International Relations, edited by Thomas Davies. London: Routledge.

Heiss, Andrew, and Tana Johnson. 2016. "Internal, Interactive, and Institutional Factors: Towards a Unified Theory of INGO Behavior.” International Studies Review 18, no. 3 (September): 528-41. doi:10.1093/isr/vivo14.

Heiss, Andrew, and Judith G. Kelley. 2017. "Between a Rock and a Hard Place: International NGOs and the Dual Pressures of Donors and Host Governments.” Journal of Politics 79, no. 2 (April): 732-41. doi:10.1086/691218.

Henry, Laura A., Lisa McIntosh Sundstrom, Priya Bala-Miller, and Carla Winston. this special issue. NGO Participation in Global Governance Institutions: International and Domestic Drivers of Engagement. Working Paper.

Herman, Robert D., and David O. Renz. 2004. "Doing Things Right: Effectiveness in Local Nonprofit Organizations, A Panel Study." Public Administration Review 64, no. 6 (November): 694-704. doi:1 0.1111/j.1540-6210.2004.00416.x.

IFEX Tunisia Monitoring Group. 2005. Tunisia: Freedom of Expression under Siege. February. Accessed August 2, 2017. https://www.ifex.org/tunisia/2010/02/16/tmg_report_feb_05_free_expression_ under_seige_en.pdf.

- 2010. Behind the Façade: How a Politicised fudiciary \& Administrative Sanctions Undermine Tunisian Human Rights. June 6. Accessed August 2, 2017. https://www.ifex.org/tunisia/2010/o6/ 18/ifextmgmissionreport_june2010.pdf.

International Refugee Rights Initiative. 2015. Reports and Accounts for the Year Ended 31 fanuary 2015. Reading, UK.

Kerlin, Janelle. 2006. "U.S.-Based International NGOs and Federal Government Foreign Assistance: Out of Alignment?" Chap. 11 in Nonprofits and Government: Collaboration and Conflict, edited by Elizabeth T. Boris and C. Eugene Steuerle, 373-98. Washington, D. C.: Urban Institute.

Kim, Mirae, and Gregg G. Van Ryzin. 2014. "Impact of Government Funding on Donations to Arts Organizations: A Survey Experiment." Nonprofit and Voluntary Sector Quarterly 43, no. 5 (October): 910-25. doi:10.1177/089976401348780o.

Landman, Todd, and Meghna Abraham. 2004. Evaluation of Nine Non-Governmental Human Rights Organisations. IOB Working Document. The Hague: Inspectie Ontwikkelingssamenwerking en Beleidsevaluatie (IOB), February.

Oster, Sharon M. 1992. "Nonprofit Organizations as Franchise Operations." Nonprofit Management and Leadership 2 (Spring): 223-38. doi:10.1002/nml.4130020303.

Pallas, Christopher L., and Lan Nguyen. 2018. "Transnational Advocacy Without Northern NGO Partners: Vietnamese NGOs in the HIV/AIDS Sector." Nonprofit and Voluntary Sector Quarterly 47, no. ${ }_{4} \mathrm{~S}$ (August): 159 S-176S. doi:10.1177/0899764018758462.

Renz, David O. 2004. "Governance of Nonprofits." In Philanthropy in America: A Comprehensive Historical Encyclopedia, edited by Dwight F. Burlingame, 191-99. Santa Barbara, CA: ABC-CLIO.

Stiles, Kendall W. 2002. Civil Society by Design: Donors, NGOs, and the Intermestic Development Circle in Bangladesh. Westport, CT: Praeger. 
Stroup, Sarah S. 2012. Borders among Activists: International NGOs in the United States, Britain, and France. Ithaca, New York: Cornell University Press. doi:10.7591/9780801464256.

Tallberg, Jonas, Lisa M. Dellmuth, Hans Agné, and Andreas Duit. 2018. "NGO Influence in International Organizations: Information, Access and Exchange." British fournal of Political Science 48 , no. 1 (January): 213-38. doi:10.1017/Sooo712341500037X.

Watson, Mary R., and Rikki Abzug. 2010. "Recruitment and Retention in Nonprofit Organizations." Chap. 24 in The Jossey-Bass Handbook of Nonprofit Leadership and Management, 3rd ed., edited by David O. Renz, 669-708. San Francisco: Jossey-Bass.

Witesman, Eva, and Andrew Heiss. 2016. "Nonprofit Collaboration and the Resurrection of Market Failure: How a Resource-Sharing Environment Can Suppress Social Objectives." Voluntas: International fournal of Voluntary and Nonprofit Organizations: 1-29. doi:10.1007/s11266-016-9684-5.

Wong, Wendy H. 2012. Internal Affairs: How the Structure of NGOs Transforms Human Rights. Ithaca: Cornell University Press. doi:10.7591/9780801466069. 